\title{
Gorontalo
}

\author{
J ournal of GovernentandPditica Studies \\ Volume 2 - N0. 2 - Oktober 2019 \\ P-ISSN: 2614-2120 E-ISSN: 2614-2104
}

\section{Merit System dalam Pengisian Jabatan Pimpinan Tinggi di Kabupaten Mamuju Tengah}

\author{
Rara Novrayanti Salman \\ Universitas Tomakaka Mamuju \\ Mamunyu, Kec. Mamuju, Kabupaten Mamuju, Sulawesi Barat 91511 \\ raranovrayanti06@gmail.com
}

Received: 8th July 2019; Revised: 4th September 2019;

Accepted: 4th September 2019;

\begin{abstract}
Merit System in ASN Act 2014 is defined as qualification, competence and performance of employees. This study aimed to describe and analyze the filling of first high leadership positions in Central Mamuju Regency, West Sulawesi was seen from merit system. The data collection in this research was done by observation, interview, and documentation. Data were analyzed by using qualitative analysis. The results showed that the overall merit system had not been applied in the filling of high-ranking leadership position in Central Mamuju Regency, West Sulawesi. The filling of the top management positions by the Government of Central Mamuju Regency, West Sulawesi was conducted in Job Fit and Inauguration. However, the procedure for filling in the top leadership position in Central Mamuju Regency had resembled merit system. It was because based on Letter of Minister of State for State Apparatus Empowerment No. B/3116/M.PANRB/09.2016, stated that the positions auction may be done by sharing the same colleges or other assessors such as Institute of State Administration and State Personnel Board, and this had also been done by Central Mamuju Regency Government. In addition, the principles of merit system such as education and training, experience, skills, ethics and work performance are also contained and elaborated in 42 items of assessment made by Head of Organization and Management and State Personnel Board of Central Mamuju Regency. One of the reasons had hot been implemented the merit system as a whole in Central Mamuju Regency was because the current Secretary off Office was skill filled by task executive, there is no definitive Secretary yet. In addition, the budget issue was also another reason, because for one of the Regional Device Work Unit only if the merit system requires Rp. 7.000.000.
\end{abstract}

Keywords: merit system; filling position

\begin{abstract}
Abstrak
Merit system dalam Undang-Undang ASN 2014 diartikan sebagai kualifikasi, kompetensi dan kinerja pegawai. Penelitian ini bertujuan untuk mendeskripsikan dan menganalisis pengisian jabatan pimpinan tinggi pratama di Kabupate Mamuju Tengah Sulawesi Barat dilihat dari merit system. Pengumpulan data dalam penelitian ini dilakukan melalui observasi, wawancara, dan dokumentasi. Hasil penelitian menunjukkan bahwa secara keseluruhan merit system belum diterapkan dalam pengisian jabatan pimpinan tinggi pratama di Kabupaten Mamuju Tengah Sulawesi Barat. Pengisian jabatan pimpinan tinggi pratama yang dilaksanakan oleh Pemerintah Kabupaten Mamuju Tengah dilakukan secara Job Fit dan Pengukuhan. Akan tetapi, prosedur dalam pengisian jabatan pimpinan tinggi pratama di Kabupaten Mamuju Tengah telah menyerupai merit
\end{abstract}


system. Hal ini karena berdasarkan surat edaran MENPAN Nomor B/3116/M.PANRB/09/2016, menyatakan bahwa lelang jabatan itu boleh dilakukan dengan sharing sama perguruan tinggi atau assessor lainnya seperti LAN dan BKN, dan hal ini pun telah dilakukan oleh Pemerintah Kabupaten Mamuju Tengah. Selain itu, prinsip merit system seperti pendidikan dan pelatihan, pengalaman, keterampilan, etika dan prestasi kerja juga termuat dan dijabarkan dalam 42 item penilaian yang di buat oleh Kabag Ortala dan BKD Kabupaten Mamuju Tengah. Salah satu alasan belum diterapkannya merit system secara keseluruhan di Kabupaten Mamuju Tengah adalah karena jabatan Sekda saat ini masih diisi oleh pelaksana tugas, belum ada Sekda definitif. Selain itu, masalah anggaran juga merupakan alasan lainnya, karena untuk 1 SKPD saja jika harus merit system membutuhkan dana Rp.7.000.000.

Kata Kunci: merit system; pengisian jabatan

\section{PENDAHULUAN}

Penempatan pegawai sejatinya dimaksudkan bukan hanya untuk kemajuan suatu organisasi tetapi penempatan pegawai juga dimaksudkan sebagai suatu motivasi bagi para pegawai sehingga menimbulkan antusias, kreativitas, dan semangat kerja yang tinggi untuk menyelesaikan pekerjaan. Penempatan pegawai yang tepat juga merupakan sebuah peluang bagi pegawai untuk mengembangkan kemampuan dan keterampilannya menuju prestasi kerja yang diharapkan. Penempatan pegawai yang berdasarkan pada kecakapan pegawai disebut juga dengan merit system. Merit system oleh Wungu (2003) didefinisikan sebagai "pengelolaan sumber daya manusia yang didasarkan pada prestasi (merit) yaitu segenap perilaku kerja pegawai dalam wujudnya sebagai baik atau buruk, hal mana berpengaruh langsung pada naik atau turunnya penghasilan dan/atau karir jabatan pegawai.

Dalam praktek kepegawaian, merit system bukan saja dipergunakan pada pengangkatan pertama seorang pegawai, tetapi juga pada proses kepegawaian berikutnya, antara lain untuk menentukkan kenaikan gaji, kenaikan tingkat dan sebagainya. Sistem ini merupakan suatu sistem kepegawaian yang bersifat terbuka, kesempatan untuk menduduki suatu jabatan terbuka untuk umum, tidak terbatas pada suatu lingkungan tertentu (Saksono, 2007).

Kartono dalam Bonsafia (2017), mengatakan bahwa merit system lebih menekankan penempatan pejabat dengan memperhatikan berbagai aspekaspek, yaitu pendidikan dan pelatihan, masa kerja, pengalaman, keterampilan, prestasi kerja dan etika. Merit system dalam Undang-Undang ASN Nomor 5 Tahun 2014 diartikan sebagai kebijakan dan manajemen ASN yang berdasarkan pada kualifikasi, kompetensi, dan kinerja yang secara adil dan wajar dengan tanpa membedakan latar belakang politik, ras, warna kulit, agama, asal usul, jenis kelamin, status pernikahan, umur, atau kondisi kecatatan. Kualifikasi, kompetensi, dan kinerja seorang pegawai ASN haruslah mendapat perhatian khususnya saat seseorang hendak di tempatkan pada posisi atau jabatan tertentu misalnya saja jabatan pimpinan tinggi pratama sehingga setiap orang yang ditempatkan mampu mempertanggungjawabkan kinerjanya sesuai dengan tugas pokok dan fungsinya.

Kabupaten Mamuju Tengah sebagai daerah pemekaran baru tentunya menjadi sasaran menarik untuk ditelusuri lebih lanjut terkait pengisian jabatannya. Apalagi dengan keluarnya surat edaran MENPAN Nomor B/3116/M.PANRB/09/2016 sebagai jawaban atas keluarnya Peraturan Pemerintah Nomor 18 Tahun 2016 tentang Perangkat Daerah, maka Pengisian Jabatan Pimpinan Tinggi pun mengalami penyesuaian. 
Pengisian Jabatan Pimpinan Tinggi Pratama yang dilakukan oleh Pemerintah Kabupaten Mamuju Tengah banyak menuai berbagai tanggapan. Sebab sebagai daerah yang baru mekar kurang lebih 6 tahun, Kabupaten Mamuju Tengah sudah memiliki 2 (dua) orang PJ Bupati. Terlebih lagi diketahui bahwa latar belakang dari PJ Bupati dipengaruhi oleh kedekatan emosional Pemerintah Provinsi Sulawesi Barat. Sehingga dengan adanya fenomena ini, ada keraguan dalam keabsahan pengisian jabatan pimpinan tinggi yang dilakukan Pemerintah Kabupaten Mamuju Tengah karena jangan sampai pengisian jabatan pimpinan tinggi yang dilakukan ada unsur politik di dalamnya.

Penelitian tentang merit system ini pernah dilakukan sebelumnya oleh Baharuddin \& Djabbar (2014), dengan judul Mengurai Merit System dalam Penempatan Jabatan Struktural. Hasil penelitian menunjukkan bahwa pertimbangan-pertimbangan dalam penempatan aparatur dalam jabatan yang dilakukan oleh BAPERJAKAT dan PPK di lingkup Pemerintah Kabupaten Mamuju Tengah cenderung mengesampingkan persyaratan keahlian /keterampilan dan kualifikasi serta prestasi kerja. Selain itu, hasil penelitian juga menunjukkan bahwa belum tersedianya informasi tentang promosi jabatan dan pengambangan karir apartur di Mamuju Tengah. Penelitian sebelumnya juga pernah dilakukan oleh Setyowati (2016), dengan judul Merit System in Recruitment and Selection Process of Civil Servant Candidate in Malang Indonesia (Implementation of Recruitment and Selection of Civil Servant Candidate in 2010). Hasil penelitian menunjukkan bahwa proses rekrutmen dan seleksi tidak berdasarkan prinsip prestasi, yang ditandai dengan penyerahan formasi yang tidak berdasarkan kebutuhan birokrasi, indikasi korupsi, kolusi dan nepotisme, dan pelamar tidak dianalisis berdasarkan passing grade mereka. Tujuan dalam penelitian ini adalah untuk mendeskripsikan dan menganalisis pengisian jabatan pimpinan tinggi di Kabupaten Mamuju Tengah dilihat dari merit system.

\section{METODE PENELITIAN}

Penelitian ini menggunakan metode kualitatif dengan harapan mampu mendeskripsikan dan menganalisis pengisian jabatan pimpinan tinggi pratama di Kabupaten Mamuju Tengah dilihat dari merit system. Penelitian kualitatif adalah penelitian yang bermaksud untuk memahami fenomena tentang apa yang dialami oleh subyek penelitian, misalnya perilaku, persepsi, motivasi, tindakan, dll., secara holistik (utuh) dan dengan cara deskripsi dalam bentuk kata-kata dan bahasa pada suatu konteks khusus yang alamiah dengan memanfaatkan berbagai metode alamiah (Moleong, 2010). Penelitian ini dilakukan pada Badan Pertimbangan Jabatan dan Kepangkatan (BAPERJAKAT) Kabupaten Mamuju Tengah.

\section{HASIL DAN PEMBAHASAN}

Pengisian jabatan pimpinan tinggi pratama di Kabupaten Mamuju Tengah merujuk pada surat edaran MENPAN Nomor B/3116/M.PANRB/09/2016 yang merupakan jawaban atas keluarnya Peraturan Pemerintah Nomor 18 Tahun 2016 tentang Perangkat Daerah. Terdapat beberapa point yang menjadi sorotan dalam surat edaran MENPAN tersebut, yakni : 1) Pejabat pimpinan tinggi yang dikukuhkan adalah bagi mereka yang sudah duduk dalam jabatan eselon II b (Kepala Dinas) yang setelah di uji di tempatkan pada SKPD itu lagi (tidak mengalami pergeseran instansi). 2) Pengisian jabatan pimpinan tinggi yang 
dilaksanakan bagi mereka yang sudah duduk dalam jabatan eselon II b (Kepala Dinas) untuk melihat kesesuaian antara jabatan saat ini dengan kualifikasi, kompetensi dan kinerja Kepala Dinas tersebut dan jika setelah dilakukan Job Fit ternyata lebih cocok di Dinas lain, setelah itu dipindahkan maka itu adalah hasil job fit. 3) Pengisian jabatan pimpinan tinggi yang dilakukan melalui seleksi terbuka atau yang lebih akrab dikenal dengan sebutan merit system akan dilakukan bagi jabatan-jabatan yang masih lowong.

Sesuai dengan surat edaran MENPAN Nomor B/3116/M.PANRB/09/2016, pelaksanaan jabatan pimpinan tinggi pratama di Kabupaten Mamuju Tengah dilakukan berdasarkan Job Fit dan Pengukuhan. Sementara untuk merit system belum bisa diterapkan secara keseluruhan di Kabupaten Mamuju Tengah. Meskipun demikian, prinsip dari pada merit system seperti pendidikan dan pelatihan, pengalaman, keterampilan, etika dan prestasi kerja telah diterapkan dalam pengisian jabatan pimpinan tinggi pratama di Kabupaten Mamuju Tengah. Terdapat beberapa alasan mengapa merit system belum bisa diterapkan secara keseluruhan di Kabupaten Mamuju Tengah, yakni : 1) belum adanya Sekda definitif. Sejak pemekaran Kabupaten Mamuju Tengah hingga saat ini masih dipimpin oleh Pelaksana Sekda. 2) Munculnya gejolak-gejolak yang terjadi di daerah pasca pemekaran yang menimbulkan banyak tuntutan terutama bagi para Tim Pemekaran yang telah berjuang dan turut serta dalam Pemekaran Mamuju Tengah bahwa yang menjadi prioritas utama dalam jabatan pimpinan tinggi adalah putera puteri asli daerah. Padahal dalam Undang-Undang ASN telah jelas disebutkan bahwa setiap pegawai memiliki kesempatan yang sama secara adil dan wajar tanpa ada diskriminasi atau tanpa membedakan latar belakang politik, ras, warna kulit, agama, asal usul, jenis kelamin, status pernikahan, umur, atau kondisi kecatatan. 3) Masalah anggaran. Banyaknya persiapan untuk melakukan pengisian jabatan pimpinan tinggi yang sesuai dengan kualifikasi, kompetensi dan kinerja pegawai sehingga Tim Panitia Seleksi jabatan pimpinan tinggi haruslah Tim yang kompeten dibidangnya. Untuk itu, sangatlah penting untuk membentuk Tim Assessor. Akan tetapi, biaya untuk membentuk Tim Assessor tidaklah murah karena untuk 1 jabatan pimpinan tinggi jika mau merit system membutuhkan biaya sekitar Rp. 7.000.000.

Dengan demikian, jabatan-jabatan seperti Sekda, Kepala Dinas Perhubungan, Kepala Dinas Pertanian, Kepala Dinas Pekerjaan Umum, Kepala Badan Keuangan, Kepala Bappeda, dan Litbang yang hingga saat ini masih diisi oleh pelaksana-pelaksana tugas kedepannya akan dilelang sebagaimana merit system yang sesungguhnya. 


\section{Tabel 1. Hasil Job Fit Pengisian Jabatan Pimpinan Tinggi Pratama bagi eselon II b di Kabupaten Mamuju Tengah}

\begin{tabular}{|c|c|c|}
\hline Nama & lama & baru \\
\hline Ishaq Yunus, S.IP, M.A.P & $\begin{array}{l}\text { Sekertaris Badan } \\
\text { Kepegawaian Pendidikan } \\
\text { dan Pelatihan Kabupaten } \\
\text { Mateng }\end{array}$ & $\begin{array}{l}\text { Asisten Bidang } \\
\text { Pemerintahan Sekretariat } \\
\text { Daerah }\end{array}$ \\
\hline $\begin{array}{l}\text { M. Yusuf Unja, S.Pd, } \\
\text { M.Pd }\end{array}$ & $\begin{array}{l}\text { Kepala Bagian Ekonomi } \\
\text { Sekretariat Daerah }\end{array}$ & $\begin{array}{l}\text { Asisten Bidang } \\
\text { Pembangunan Sekretariat } \\
\text { Daerah }\end{array}$ \\
\hline Bahri, S.IP & $\begin{array}{l}\text { Camat Pangale } \\
\text { Kabupaten Mateng. }\end{array}$ & $\begin{array}{l}\text { Asisten Bidang } \\
\text { Administrasi Daerah }\end{array}$ \\
\hline Sakaria, K.S.Ag & $\begin{array}{l}\text { Kepala Bagian Hukum } \\
\text { Sekretariat DPRD } \\
\text { Kabupaten Mateng. }\end{array}$ & Sekertaris DPRD \\
\hline Drs. H. Adnas, M.Si & $\begin{array}{l}\text { Inspektur Pembantu } \\
\text { Wilayah III Kabupaten } \\
\text { Mateng }\end{array}$ & Inspektur Inspektorat \\
\hline Ir. H. Amrullah, MM & $\begin{array}{l}\text { Sekertaris Dinas } \\
\text { Kelautan dan Perikanan } \\
\text { Kabupaten Mateng }\end{array}$ & $\begin{array}{l}\text { Kepala Dinas Kelautan } \\
\text { dan Perikanan }\end{array}$ \\
\hline $\begin{array}{l}\text { Drs. Bambang Suparni, } \\
\text { MM. }\end{array}$ & $\begin{array}{l}\text { Kepala Bagian } \\
\text { Persidangan dan Hukum } \\
\text { Sekretariat DPRD } \\
\text { Kabupaten Mateng }\end{array}$ & $\begin{array}{l}\text { Kepala Dinas } \\
\text { Perpustakaan dan } \\
\text { Kearsipan }\end{array}$ \\
\hline $\begin{array}{l}\text { H. Abd. Latif Settaring, } \\
\text { M.A.P }\end{array}$ & $\begin{array}{l}\text { Sekretaris Dinas } \\
\text { Pendidikan dan } \\
\text { Informatika Kabupaten } \\
\text { Mateng }\end{array}$ & $\begin{array}{l}\text { Kepala Dinas Persandian } \\
\text { Komunikasi dan } \\
\text { Informatika }\end{array}$ \\
\hline $\begin{array}{l}\text { Hasanuddin, HW, S.Ag, } \\
\text { M.Si }\end{array}$ & $\begin{array}{l}\text { Sekretaris Dinas } \\
\text { Ketentraman dan } \\
\text { Ketertiban Umum Serta } \\
\text { Perlindungan Masyarakat } \\
\text { Kabupaten Mateng }\end{array}$ & $\begin{array}{l}\text { Kepala Dinas } \\
\text { Kependudukan } \\
\text { Pencatatan Sipil }\end{array}$ \\
\hline $\begin{array}{l}\text { Drs. H. Muhammad } \\
\text { Samsir, M.Pd }\end{array}$ & $\begin{array}{l}\text { Sekretaris Dinas } \\
\text { Perhubungan Kabupaten } \\
\text { Mateng }\end{array}$ & $\begin{array}{l}\text { Kepala Dinas } \\
\text { Ketentraman dan } \\
\text { Ketertiban Umum Serta } \\
\text { Perlindungan Masyarakat }\end{array}$ \\
\hline Jasman. S, S.Pd, M.Pd & $\begin{array}{l}\text { Sekretaris Dinas } \\
\text { Perumahan Rakyat dan } \\
\text { Kawasan Pemukiman } \\
\text { Kabupaten Mateng }\end{array}$ & $\begin{array}{l}\text { Kepala Dinas Perumahan } \\
\text { Rakyat dan Kawasan } \\
\text { Pemukiman }\end{array}$ \\
\hline Ir. H. Ruslan Lazim & $\begin{array}{l}\text { Aisten Bidang } \\
\text { Administrasi Sekretariat } \\
\text { Daerah Kabupaten } \\
\text { Mateng }\end{array}$ & Kepala Dinas Pertanian \\
\hline Hj. Asmira Djamal, SE, & Sekretaris Dinas & Kepala Dinas Pariwisata, \\
\hline
\end{tabular}


$\mathrm{M}, \mathrm{Si}$

Setya Bero, SKM

H. Mulyadi, SE,

Dzulkifli, S.IP.

Rahmat Syam, S.Pd, M.A.P, .

Abd. Rajab, S.Sos

Muh. Anwar, S.Ip,

M.A.P.

Drs. H. Saharuddin Tinggi
Pariwisata, Pemuda dan

Olahraga Kabupaten

Mateng

Sekretaris Dinas

Pengendalian Penduduk

dan KB Serta

Pemberdayaan

Perempuan dan

Perlindungan Anak

Kabupaten Mateng

Sekretaris Dinas

Lingkungan Hidup

Kabupaten Mateng.

Sekretaris Dinas

Pemberdayaan

Masyarakat dan Desa

Kabupaten Mateng

Sekretaris Badan

Penanggulangan

Bencana Daerah

Kabupaten Mateng

Sekretaris Inspektorat

Kabupaten Mateng

Sekretaris Dinas Sosial

Kabupaten Mateng

Kepala Kantor Kesatuan

Bangsa dan Politik

Kabupaten Mateng
Pemuda dan Olahraga

Kepala Dinas

Pengendalian Penduduk

dan KB Serta

Pemberdayaan

Perempuan dan

Perlindungan Anak

Kepala Dinas Lingkungan Hidup

Kepala Dinas

Pemberdayaan

Masyarakat dan Desa

Kepala Badan

Penanggulangan Bencana

Daerah.

Staf Ahli Bidang

Pemerintahan, Hukum

dan Politik

Staf Ahli Bidang

Ekonomi,

Pembangunan dan

Keuangan

Staf Ahli Kemasyarakatan

dan Sumberdaya Manusia

Sumber : BKPSDM Kabupaten Mamuju Tengah 2017

Table 1 memperlihatkan Pengisian jabatan pimpinan tinggi pratama di Kabupaten Mamuju Tengah yang dilakukan melaui job dengan standar merit system. Berdasarkan pengisian jabatan yang dilakukan pada tanggal 1 Januari 2016, diketahui bahwa terdapat 15 orang Kepala Dinas yang di pindahkan atau di job fit sesuai dengan kemampuan dan klasifikasi pendidikan maupun kompentensinya selama ini.

Pengisian jabatan pimpinan tinggi pratama di Kabupaten Mamuju Tengah dilakukan melalui pengukuhan. Dari hasil pengisian jabatan yang dilakukan pula diperoleh informasi bahwa terdapat 9 orang Kepala Dinas yang masih dipertahankan karena dianggap sudah sesuai antara posisi yang yang diduduki saat ini dengan kualifikasi, kompetensi dan kinerjanya selama ini.

Hasil job fit dan pengukuhan yang dianggap Pemerintah Kabupaten Mamuju Tengah merupakan hasil penilaian yang valid berdasarkan kualifikasi, kompetensi dan kinerja sebagaimana merit system pada umumnya, nyatanya banyak menimbulkan keraguan di dalamnya. 
Tabel 3 memperlihatkan dari segi pendidikan masih terdapat beberapa Kepala Dinas yang memiliki latar belakang jurusan pendidikan dan latar belakang profesi adalah guru yang berhubungan dengan riwayat jabatannya. Sehingga dari segi pengalaman juga menimbulkan pertanyaan karena peryaratan yang telah dibuat untuk setiap indikator pengalaman jabatan Kepala Dinas berbeda-beda sesuai dengan jabatannya masing-masing. Kaitannya dengan pendidikan adalah mengenai persyaratan yang telah dibuat oleh Pemerintah Mamuju Tengah yang memberikan peluang kepada semua jurusan untuk mendaftar menjadi Kepala Dinas. Akibanya adalah antara tidak koneksnya antara persyaratan jurusan dengan pengalaman jabatan.

\section{Tabel 2. Indikator Kompetensi Manajerial yang Menjadi Penilaian dalam Pengisian Jabatan Pimpinan Tinggi Pratama di Kabupaten Mamuju Tengah}

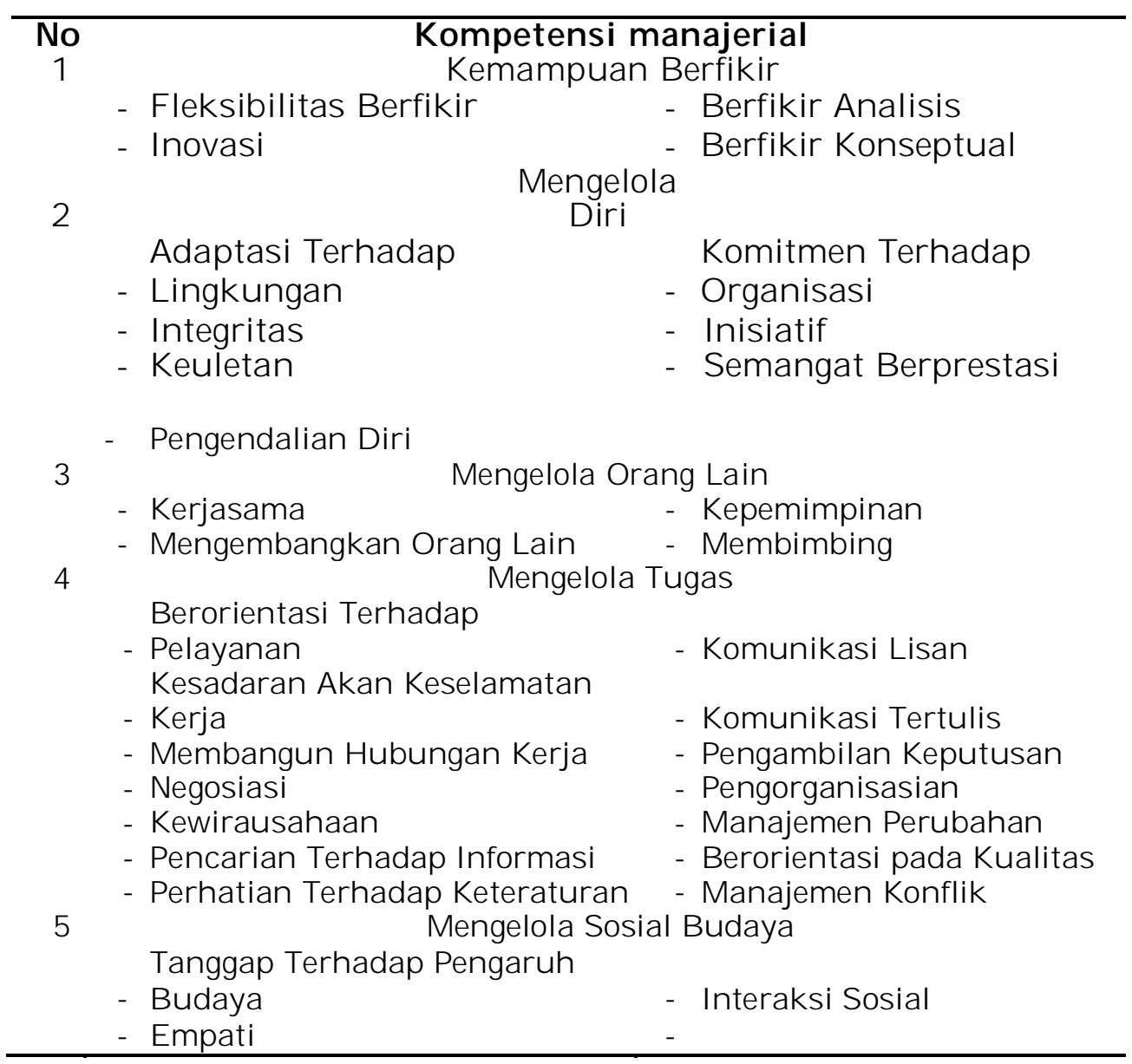

Sumber : BKPSDM Kabupaten Mamuju Tengah 2017

Table 2 menunjukkan Indikator-indikator yang menjadi persyaratan dalam penilaian pengisian jabatan pimpinan tinggi pratama dari segi keterampilan, hasilnya secara keseluruhan adalah Pemerintah Kabupaten Mamuju Tengah memang sudah membuat rincian persyaratan secara detail tentang apa-apa saja yang menjadi ukuran dalam pengisian jabatan pimpinann tinggi pratama dari segi keterampilannya yang biasa disebut kompetensi manajerial. 
Dari segi etika, peryaratan yang dibuat untuk menjadi Kepala Dinas nyatanya masih memiliki kekurangan terutama mengenai etika dalam bekerja. Hal ini ditunjukkan dengan adanya aksi demontrasi yang dilakukan oleh masyarakat Kabupaten Mamuju Tengah yang meminta pertanggungjawaban PJ Bupati atas pengangkatannya Kepala Dinas-Kepala Dinas yang tidak kompeten dibidangnya dengan menyalahgunakan tugas dan fungsinya dengan melakukan tindakan KKN (Korupsi, Kolusi, dan Nepotisme).

Tabel 3. Indikator Penilaian Prestasi Kerja di Kabupaten Mamuju Tengah

\begin{tabular}{|c|c|c|c|}
\hline Unsur yang dinilai & Nilai & Ket. & Jumlah \\
\hline $\begin{array}{l}\text { Sasaran Kerja Pegawai } \\
\text { (SKP) Perilaku Kerja }\end{array}$ & & & \\
\hline $\begin{array}{ll}\text { - } & \text { Orientasi Pelayanan } \\
- & \text { Integritas } \\
- & \text { Komitmen } \\
- & \text { Disiplin } \\
- & \text { Kerjasama } \\
- & \text { Kepemimpinan } \\
- & \text { Jumlah } \\
- & \text { Nilai rata-rata } \\
\end{array}$ & & & \\
\hline
\end{tabular}

Tabel 3 memperlihatkan karakteristik penilaian pengisian jabatan pimpinan tinggi pratama dari segi prestasi kerja. Persyaratan yang dibuat untuk menjadi Kepala Dinas merupakan persyaratan yang sesuai dengan Peraturan Pemerintah Nomor 46 Tahun 2011 Tentang Penilaian Prestasi Kerja Pegawai Negeri Sipil.

Penelitian ini menunjukkan bahwa upaya yang dilakukan oleh Pemerintah Kabupaten Mamuju Tengah untuk melaksanakan pengisian jabatan pimpinan tinggi pratama yang berdasarkan kualifikasi, kompetensi dan kinerja dapat dilihat dengan adanya 42 item penilaian yang dibuat oleh Kepala BKD dan Kabag Ortala yang memuat tentang prinsip-prinsip merit system seperti pendidikan dan pelatihan, pengalaman, keterampilan, etika dan prestasi kerja (Kartono, 2001).

Pada dasarnya pendidikan dan pelatihan memang menjadi salah satu persyaratan penting dalam pengisian jabatan pimpinan tinggi pratama di Kabupaten Mamuju Tengah. Pendidikan dan pelatihan pegawai sering disebut diklat. Dalam kepegawaian diklat pegawai negeri sipil terbagi atas 5 yakni : diklat prajabatan, diklat dalam jabatan, diklat kepemimpinan, diklat fungsional dan diklat teknis (Sopha, 2011). Pendidikan dan pelatihan bagi pegawai di Kabupaten Mamuju Tengah belumlah optimal. Hal ini karena masih terdapat Kepala Dinas yang tidak sesuai antara pendidikan dan relevansi jabatan yang diduduki. Salah satu penyebabnya adalah kurang tegasnya Pemerintah Kabupaten Mamuju Tengah dalam pengisian jabatan pimpinan tinggi pratama. Hal ini sebab dalam prosedur pengisian jabatan pimpinan tinggi yang telah dibuat oleh BKD dan Kabag Ortala tidak melarang tegas masuknya guru dalam birokrasi. Anehnya, surat edaran MENPAN Nomor : SE/15/M/PAN/4/2004 tentang larangan pengalihan guru dalam jabatan structural telah lama 
dikeluarkan. Namun, meskipun demikian Kepala Dinas yang berlatar belakang guru masih diperbolehkan masuk dalam birokrasi. Padahal jabatan profesi yang beralih dari guru ke struktural tentu memiliki dampak bagi jalannya birokrasi. Seorang guru yang terlibat dalam jabatan struktural jika memiliki pengetahuan yang kurang tentang jabatan yang akan pimpinannya terlebih lagi jika jabatan itu adalah jabatan strategis seperti Kepala Dinas, maka peluang keberhasilan untuk menjalankan tugas tersebut sangatlah sedikit karena yang terjadi adalah penyesuaian untuk melaksanakan tugas sehingga program-program yang ingin dicapai masih terbengkalai.

Pengalaman dapat dikatakan sebagai sebuah pembelajaran yang paling berharga sehingga dengan adanya pengalaman terhadap sesuatu maka hal itu akan menjadi pembelajaran untuk perubahan yang lebih baik. pengalaman yang dimaksud dalam penelitian ini adalah pengalaman seseorang selama menjadi pegawai ASN. Jadi, semakin luas pengalaman kerja seseorang, semakin terampil melakukan pekerjaan dan semakin sempurna pola berfikir dan sikap dalam bertindak untuk mencapai tujuan yang telah ditetapkan (Arbityani, 2004).

Kesadaran akan pentingnya faktor pengalaman juga dapat dilihat dalam pengisian jabatan pimpinan tinggi pratama,dimana dalam pengisian jabatan pimpinan tinggi pratama yang dilakukan oleh Pemerintah Kabupaten Mamuju Tengah, pengalaman menjadi salah satu indikator yang dinilai untuk menempatkan seseorang pada jabatan tertentu. Untuk itu, yang menjadi acuan dalam pengisian jabatan pimpinan tinggi pratama adalah pengalaman menduduki jabatan yang ditentukkan dengan skor. Misalnya saja untuk menjadi Kepala Dinas Pendidikan, Pemuda dan Olahraga maka pengalaman jabatannya adalah Pernah kerja pada SKPD Perencanaan, Pernah kerja pada SKPD Pengelolaan Pendidikan, Pernah jadi Kepala Sekolah.

Keterampilan sering diartikan sebagai kecakapan atau keahlian untuk melakukan suatu pekerjaan yang hanya diperoleh dalam praktek (Wahyudi, 2002). Keterampilan dalam penelitian ini merupakan gambaran salah satu indikator penting yang turut berperan dalam pengisian jabatan pimpinan tinggi pratama di kabupaten Mamuju Tengah. Hal ini sebab dari keterampilan yang dimiliki maka akan diketahui bagaimana kesiapan seorang pegawai jika ditempatkan pada jabatan tertentu. Keterampilan yang dimaksud dalam pengisian jabatan pimpinan tinggi pratama adalah kompetensi manajemerial yang merupakan bagian dari 42 item penilaian.

Jika merujuk pada 42 item penilaian yang menjadi dasar dalam pengisian jabatan pimpinan tinggi pratama di Kabupaten Mamuju Tengah maka memang untuk etika sebagian besar telah diperhitungkan dalam pengisian jabatan pimpinan tinggi pratama yang yang mencangkup bagaimana hubungannya dengan orang lain ketika menjadi Kepala Dinas, apakah pejabat tersebut adalah pejabat yang mau menerima saran dari stafnya, apakah bisa menyesuaikan diri ketika terjadi perubahan atau tidak. Pada intinya etika yang dinilai adalah hubungan interaksi atau timbal balik yang ditunjukkan. Selain itu, etika mengenai kedisiplinan pegawai juga turut diperhitungkan sebagai syarat untuk menjadi Kepala Dinas di Kabupaten Mamuju Tengah. Namun, meskipun Pemerintah Kabupaten Mamuju Tengah telah menyusun poin-poin penting terkait etika namun nyatanya hal ini pun bukanlah jaminan bahwa kinerja aparatur bisa berjalan dengan baik dan diterima oleh masyarakat umum. Hal ini karena masih terdapat beberapa Kepala Dinas di Kabupaten Mamuju Tengah yang melakukan penyimpangan terutama mengenai dana batuan BSM bagi 
murid-murid sekolah SD, SMP, dan SMA. Padahal dalam Peraturan Pemerintah Nomor 42 Tahun 2004 telah menjelaskan secara detail etika PNS.

Prestasi kerja juga merupakan bagian dari penilaian dalam pengisian jabatan pimpinan tinggi pratama di Kabupaten Mamuju Tengah. Prestasi kerja pada dasarnya memang merupakan gambaran perjuangan, usaha, dan kerja keras yang sering dilambangkan dengan kata keberhasilan. Sehingga tidak mengherankan jika dalam pengisian jabatan pimpinan tinggi di Kabupaten Mamuju Tengah juga menggunakan prestasi kerja sebagai salah satu item penilaian. Prestasi kerja yang dinilai dalam pengisian jabatan pimpnan tinggi pratama terutama mengenai rancangan program kerja ketika menempati posisi SKPD tertentu. Misalnya untuk di Dinas Pendidikan diketahui bahwa di Mamuju Tengah ini masih kekurangan beberapa sekolah misalnya SD, SMP, SMA target yang ingin dicapai tahun ini adalah penambahan 2 SMA. Misalnya lagi target selanjutnya yang ingin dicapai adalah kualitas nilai pendidikan. Apakah nanti tercapai atau tidak sama sekali tetap akan menjadi point tersendiri dalam pengisian jabatan pimpinan tinggi pratama termasuk bagaimana Kepala Dinas tersebut mengatur keuangannya untuk pembangunan semua dinilai dalam pengisian jabatan pimpinan tinggi pratama.

\section{PENUTUP}

Merit system dalam pengisian jabatan pimpinan tinggi di Kabupaten Mamuju Tengah dapat dilihat melalui prinsip merit system yang meliputi : pendidikan dan pelatihan, pengalaman, keterampilan, etika dan prestasi kerja yang diterapkan dan digunakan sebagai indikator dalam penilaian jabatan pimpinan tinggi pratama yang termuat dan dijabarkan secara detail dalam 42 item penilaian. Akan tetapi, persyaratan untuk indikator pendidikan dan pelatihan yang memperbolehkan semua jurusan untuk terlibat dalam pengisian jabatan pimpinan tinggi pratama. Akhirnya, terdapat beberapa Kepala Dinas yang berasal dari guru. Sehingga meskipun mereka memiliki latar belakang yang berbeda dengan bidang ilmunya asalkan memiliki pengalaman diposisi yang menjadi tujuan mereka, maka akan memiliki kesempatan karena pada dasarnya penilaian hanya berdasarkan angka (skor). Disarankan agar Pemerintah Kabupaten Mamuju Tengah hendaknya dalam mengisi jabatan pimpinan tinggi pratama lebih mengedepankan prinsip-prinsip merit system tanpa harus ada unsur lain seperti like and dislike.

\section{REFERENSI}

Arbityani P. (2004). Faftor-Faktor yang Berpengaruh Terhadap Kepuasan Kerja dan Kinerja Manajer Perusahaan Manufaktur. JA AI

Baharuddin \& Djabar.I. (2014). Mengurai Merit System dalam Penempatan Jabatan Struktural. Journal unhas, volume x nomor 1 Juni 2014.

Bonsafia Y.H. (2017). Merit System Rekruitmen Pejabat Struktural : Studi Kasus di Pemerintah Provinsi Papua. Disertasi unhas.

Moleong J.L. (2010). Metodologi Penelitian Kualitatif. PT Remaja Rosda Karya. Bandung.

Peraturan Pemerintah Nomor 42 Tahun 2004 Tentang Etika PNS

Peraturan Pemerintah Nomor 46 Tahun 2011 Tentang Penilaian Prestasi Kerja Pegawai Negeri Sipil.

Peraturan Pemerintah Nomor 18 Tahun 2016 tentang Perangkat Daerah. 
Saksono S. (2007). Administrasi Kepegawaian. KANISIUS ( Anggota IKAPI). Yogyakarta.

Setyowati E. (2016). Merit System in Recruitment and Selection Process of Civil Servant Candidate in Malang Indonesia (Implementation of Recruitment and Selection of Civil Servant Candidate in 2010). Diakses pada 5 Maret 2017.

Sugiyono. (2011). Metode Penelitian Kombinasi (Mixed Pethods). Alfabeta. Bandung.

Surat Edaran MENPAN Nomor B/3116/M.PANRB/09/2016 tentang Pengisian Jabatan Pimpinan Tinggi.

Surat Edaran MENPAN Nomor : SE/15/M/PAN/4/2004 tentang Larangan Pengalihan Guru dalam Jabatan Struktural.

Undang-Undang ASN Nomor 5 Tahun 2014.

Wahyudi B. (2002). Manajemen Sumber Daya Manusia. Sulita. Bandung.

Wungu J. (2003). Tingkatkan Kinerja Perusahaan Anda dengan Merit System. Jakarta : PT RajaGrafindo Persada. 